\title{
Effects of Tractor-Traffic Compaction on the Physical Properties of an Irrigated Soil in Southwestern Puerto Rico.
}

\author{
M. A. Lugo-López and G. Acevedo' \\ INTRODUCTION
}

Problems associated with soil-packing or compaction by tractor wheels or tracks have been a topic of discussion since the advent of the tractor. In fact, almost any new type of equipment developed is claimed to be capable of producing greater traction with less packing. The U. S. Department of Agriculture has conducted some work along this line, mainly at its Tillage Machinery Laboratory at Auburn, Ala. State experiment stations have shown some interest in this problem too, $(2,8,9,12){ }^{2}$ European workers have also given attention to the problems associated with soil compaction (1). No such studies have been conducted in Puerto Rico, the chief reaison being that the Island's agriculture is not yet highly mechanized. However, progress in sugarcane mechanization, although slow, has accelerated lately (figs. 1 and 2). Marked mechanical advances have been made also in corn (fig. 3) and sweetpotato (fig. 4) cultivation. Such achievements in mechanized farming are likely to continue at a gradual, but steady pace, so that agricultural progress can maintain a highly competitive and commercial basis.

With increasing use of heavy equipment on the farm the problems associated with soil compaction will be of considerable importance. Soil-structure deterioration is likely to occur. Water movement, aereation, and root development will be adversely affected, particularly in soils having a wide range of particle sizes such as loams (5). A survey in other areas has led to the conclusion that there is no easy, rapid, and economic solution to the compaction problem (3). The best approach seems to lie in minimizing soil compaction through the use of intelligent soil-management practices and techniques.

\section{OBJECTIVES}

The study reported herein presents preliminary information as to the possible immediate effects of heavy tractor traffic on an irrigated soil in southwestern Puerto Rico. It must be admitted at the outset that the results reported barely scratch the surface of this potential problem. This report

${ }^{1}$ Associate Soil Scientist and Research Assistant in Soils, respectively, Agricultural Experiment Station, University of Puerto Rico, Río Piedras, P. R.

2 Numbers in parentheses refer to Literature Cited, pp. 243-4. 


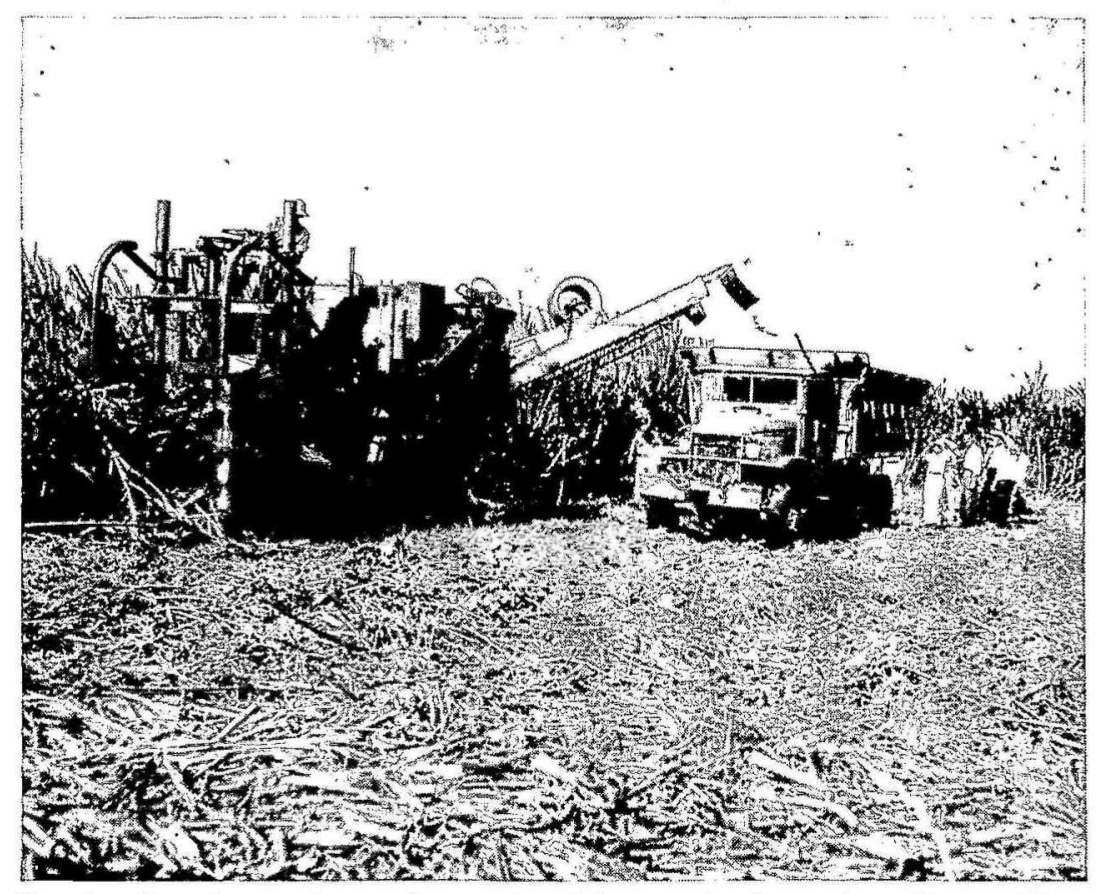

FIG. 1.-Cane-harvesting equipment in trial operation in southern Puerto Rico.

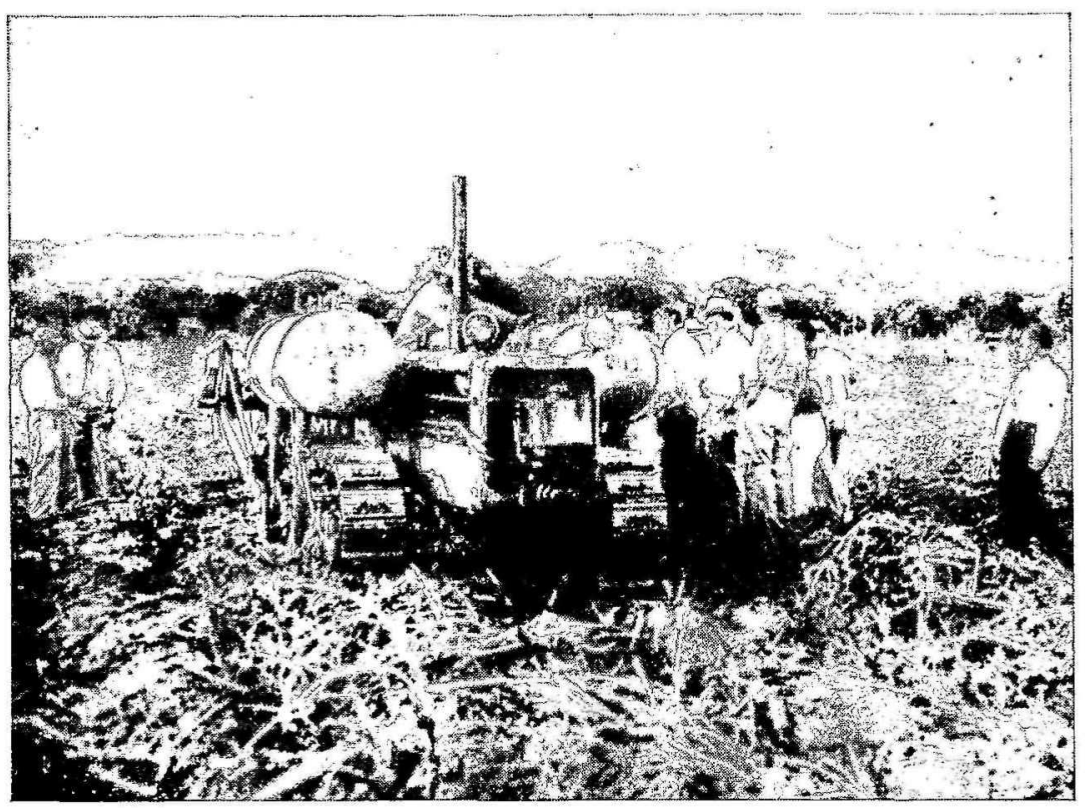

FIG. 2.-The application of fertilizer through mechanical means is becoming increasingly popular among sugarcane growers. 


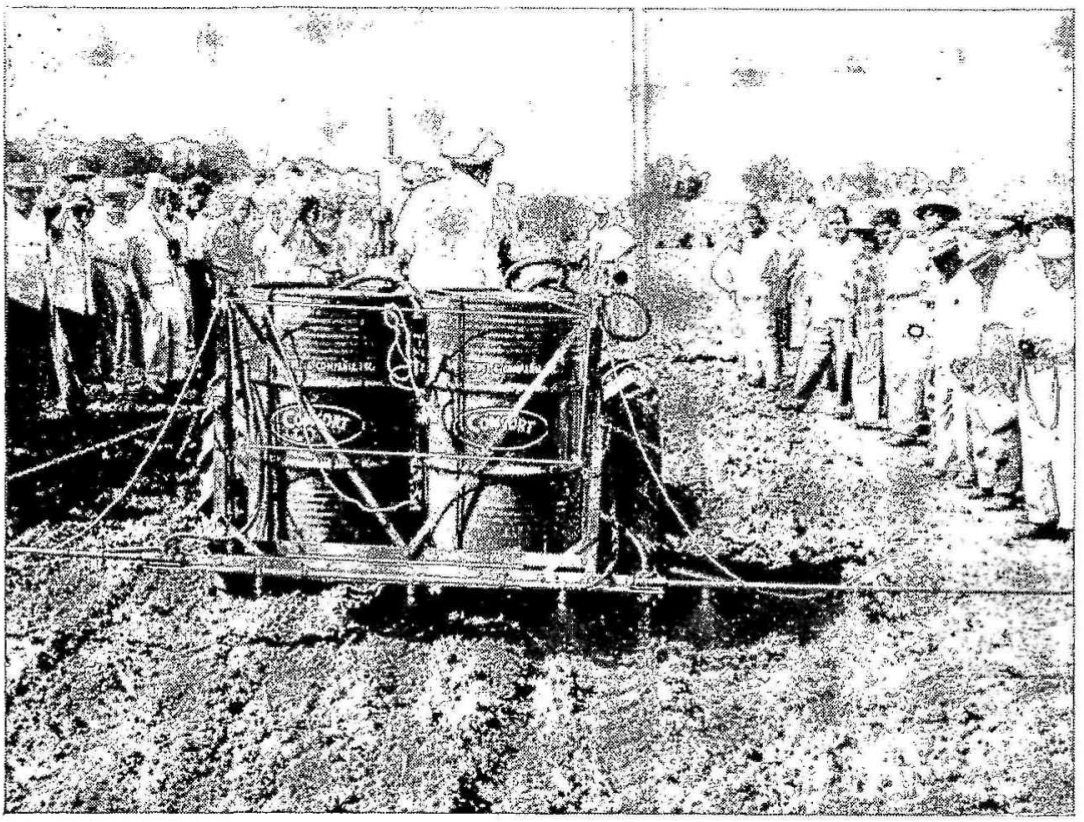

Frg. 3.-Pregermination treatment of corn fields for weed control. This photo was taken on a training field day at the Lajas Agricultural Experiment Substation.

is intended as a warning about the possible harmful effects on soils of very essential and otherwise beneficial mechanization. Most of the investigators working on these problems have been limited to the use of bulk-density changes as indices of soil compaction. They are indeed good indices, probably the best. This paper, however, in addition to measurements of bulkdensity changes, reports effects of soil compaction on the water movement and water-retention power of the soil. The data are very revealing, and it is hoped that they will open up new avenues of research looking toward a more rounded and complete understanding of the compaction problem in soils.

\section{MATERIALS AND METHODS}

Preliminary compaction studies were made on soil samples taken from a longtime fertilizer experimental field of 5-acres used to grow sugarcane at Hacienda María Antonia in southwestern semiarid Puerto Rico. This field had been in sugarcane for many years prior to establishing the experiment. The soil was classified as Vayas clay, a poorly drained soil of the river flood plains. It is deep, very fertile, and occupies nearly level areas near stream channels. At the surface it is of a dark grayish-brown color, with a rather well-developed structure. Aggregates are predominantly small, ranging 


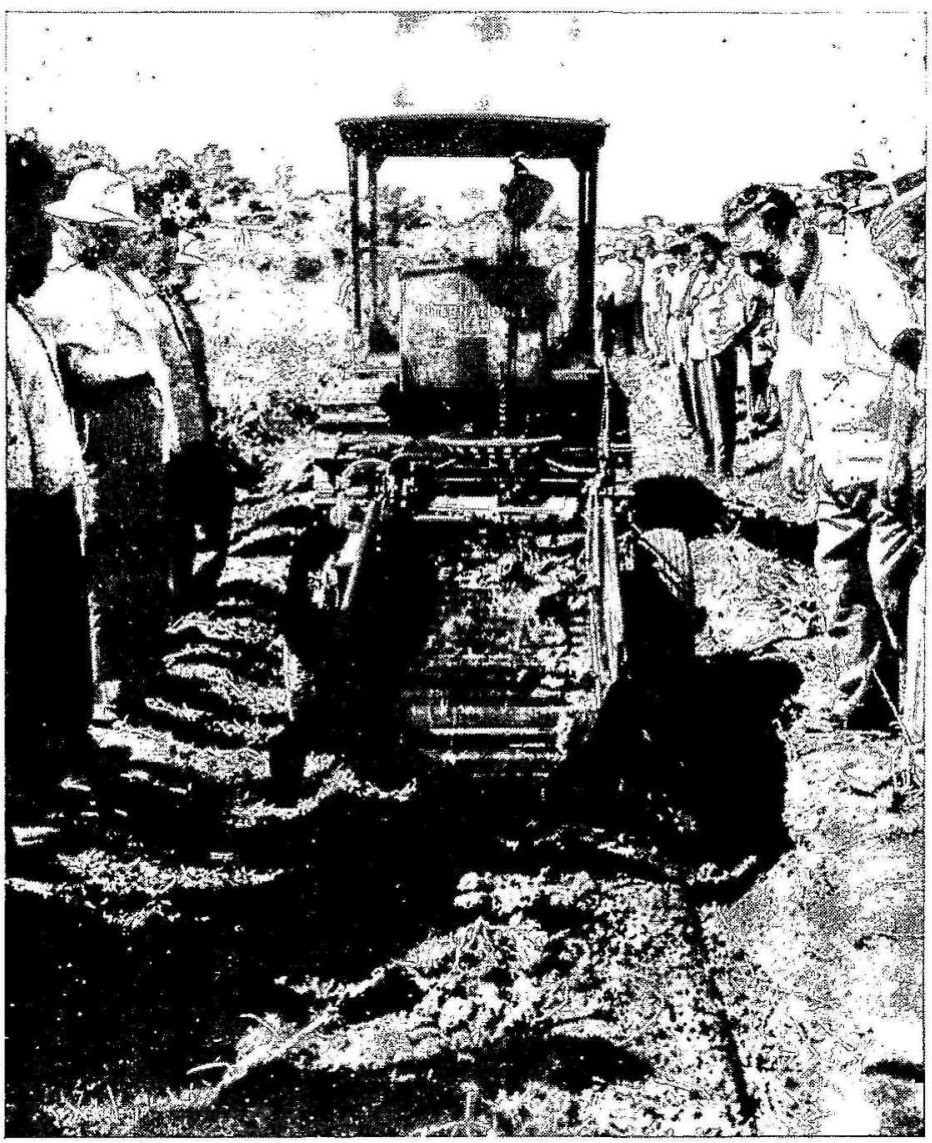

FIG. 4.- Sweetpotato-harvesting equipment in operation during another training field day at one of the Station farms.

from subangular to almost rounded, and are rather loosely packed. Beginning at a depth of 20 or 30 inches this soil becomes mottled-gray or rustbrown, and the structure is rather weakly developed with somewhat densely packed medium-large aggregates.

Undisturbed soil-core samples $\left(3^{\prime \prime} \times 3^{\prime \prime}\right)$ were taken from adjoining rows some 3 weeks after harvesting the thirteenth consecutive sugarcane crop within the sequence of the long-range fertilizer experiment. One row had been traversed recently by a heavy tractor pulling numerous 3-ton caneloaded steel cars, including the whole crop from the 5-acre field (fig. 5), while the adjoining row was not affected by this traffic. The cane shoots of the following ratoon crop from the tractor-compacted row developed weakly and needed extensive replanting. In the adjoining unaffected rows the 


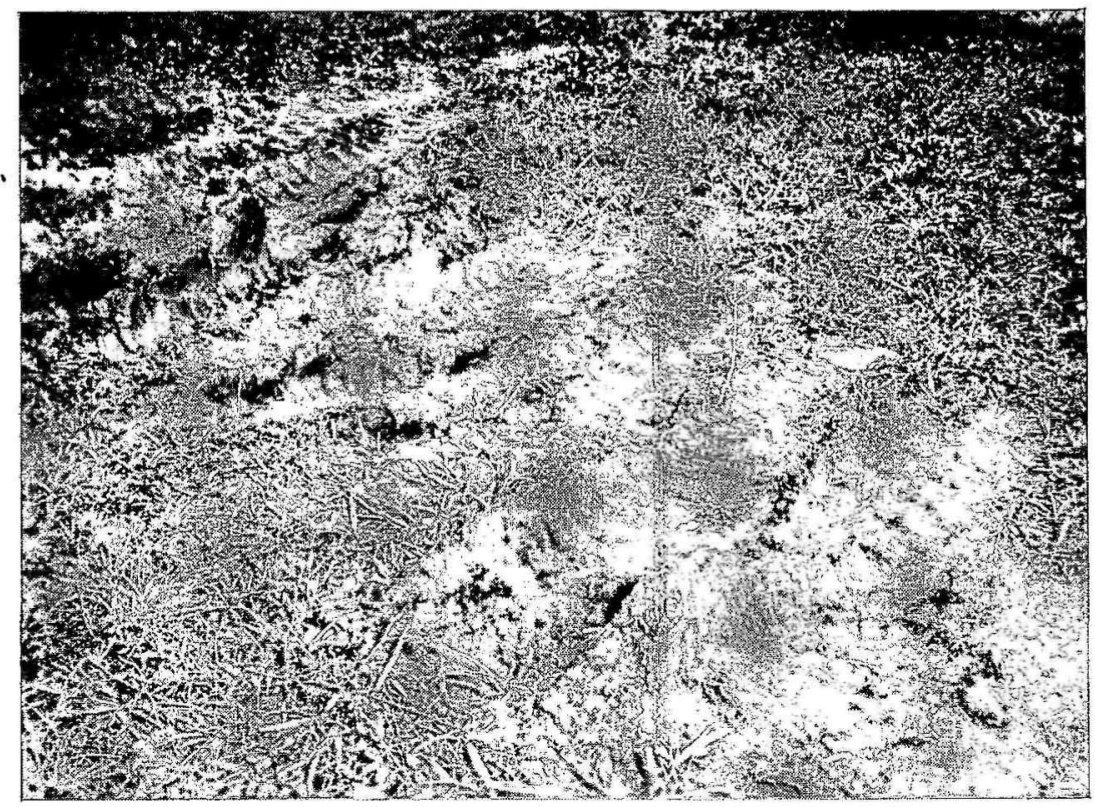

FIG. 5.-Closeup of tire-tractor impressions on moist soil.

ratoon canes developed rather vigorously. The cores were taken from five different plots along the 160-foot-wide field, by using an Uhland sampler, both at $0-3$-inch and 4-7-inch depths from each of adjacent rows, 4 feet apart. The number of blows required to take each core was recorded, and the work in sampling was calculated by multiplying the weight of the hammer of the sampler by the length of the handlebar through which the hammer slid. In addition, a bulk composite soil sample was taken from the five plots where cores were obtained.

Hydraulic-conductivity measurements were made by recording the rate at which water moved through a column of saturated soil at a known head. Quick drainage was determined by placing the saturated soil core on a Büchner funnel at a $60-\mathrm{cm}$. tension and measuring the water drained out in 15 minutes. Water removed and retained at $\mathrm{pF} 1.78$ was measured by bringing the soil core to equilibrium in a $60-\mathrm{cm}$. tension table. The soil core was finally dried at $110^{\circ} \mathrm{C}$. As the samplers used were of a known volume, the bulk density of the soil was calculatd by dividing the net dry weight of the soil by its original volume. The pore space was then calculated by assuming a specific gravity of 2.65 .

The $\mathrm{pH}$ of the composite sample was determined electrometrically by means of a Macbeth pH-meter. Organic matter was determined by the . chromic acid titration method. The mechanical composition of the soil was 
determined by the pipette method, centrifuging instead of filtering through a Chamberlain-Pasteur filter.

\section{RESULTS AND DISGUSSION}

The following tabulation gives data on the mechanical composition of the soil and its organic-matter content:

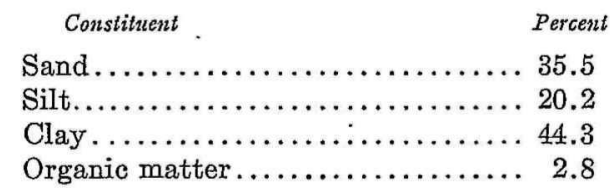

The clay content of the soil is rather high as is the case with most of the alluvial soils of the valleys in southwestern Puerto Rico. The soil is alkaline ( $\mathrm{pH}$ 8.0) with a moderately high level of organic matter.

Table 1 gives data on the immediate effect of heavy tractor traffic on some of the physical properties of this poorly drained soil. The reduction in quick drainage (water drained at $60-\mathrm{cm}$. tension in 15 minutes) with compaction is outstanding, the mean differences being significant at the 0-3-inch depth. This difference indicates restricted water movement in saturated clayey soils immediately after trampling by heavy-tractor traffic. Differences in bulk-density values between the soil subjected to heavy traffic and the untrampled soils are highly significant in the surface 3-inch layer and significant in the lower (4-7-inch) layer. The trampled soils are much denser, of course.

Data were taken as to the work required to take core samples from compacted and undisturbed soils. The mean differences are highly significant at both sampling depths. As shown in table 1 more work was required to sample the compacted soils. These could be related to the differences in work that would be required to carry on land preparation and cultivation operations in compacted and noncompacted soils. Measurements as to the draft required in both cases might be very revealing. Prevention of soil compaction might save considerable farm power.

There were highly significant and significant reductions in total pore space at the 0-3-inch and 4-7-inch depths, respectively, as indicated by the porosity values in table 1 . Highly significant differences were measured at both depths in relation to the percentage of pores drained at low tensions such as those that develop in the vicinity of $\mathrm{pF} 1.78$. However, water retention at such low tensions was not affected. This behavior indicates that, although there was a marked reduction in total pores, the micropores remained unaffected, the reduction thus being in the range of large pores (those that hold water at tensions lower than $\mathrm{pF}$ 1.78). Such a reduction 
TABLE 1.-Immediate effect of heavy-tractor trafic on some physical properities of an irrigated soil in southwestern Puerto Rico

\begin{tabular}{|c|c|c|c|c|c|c|c|c|}
\hline Soil condition & Depth & $\begin{array}{l}\text { Hy- } \\
\text { draulic } \\
\text { conduc- } \\
\text { tivity }\end{array}$ & $\begin{array}{l}\text { Water } \\
\text { drained in } \\
15 \text { minutes } \\
\text { at } 60-\mathrm{cm} . \\
\text { tension }\end{array}$ & $\begin{array}{c}\text { Bulk } \\
\text { density }\end{array}$ & $\begin{array}{l}\text { Work } \\
\text { required in } \\
\text { sampling } \\
3^{\prime \prime} \times 3^{\prime \prime} \\
\text { cores }\end{array}$ & Porosity & $\begin{array}{l}\text { Water } \\
\text { removed } \\
\text { at pF } \\
1.78\end{array}$ & $\begin{array}{l}\text { Water } \\
\text { retained } \\
\text { at pF } \\
1.78\end{array}$ \\
\hline $\begin{array}{c}\text { Compacted by } \\
\text { heavy-tractor } \\
\text { traffic......... }\end{array}$ & Inches & In./hr. & Percent & Gnt./cc. & Ft. $l b$. & Percent & Percent & Percent \\
\hline $\begin{array}{l}\text { Not affected } \\
\text { by heavy-trac- } \\
\text { tor traffic....... }\end{array}$ & $0-3$ & .335 & $6.20^{1}$ & $1.14^{1}$ & $665.69^{1}$ & $56.96^{1}$ & $3.82^{1}$ & 51.37 \\
\hline $\begin{array}{c}\text { Compacted by } \\
\text { heavy-tractor } \\
\text { traffic......... }\end{array}$ & $4-7$ & .022 & 0.20 & 1.39 & 845.39 & 47.40 & 0.00 & 50.19 \\
\hline $\begin{array}{c}\text { Not affected by } \\
\text { heavy-tractor } \\
\text { traffic........... }\end{array}$ & $4-7$ & .090 & 3.04 & $1.30^{2}$ & $698.36^{1}$ & $51.02^{2}$ & $2.84^{1}$ & 51.67 \\
\hline \multirow{2}{*}{\multicolumn{2}{|c|}{$\begin{array}{l}\text { L.S.D. for } 2 \text { treatments } \\
\text { at the same depth: }\end{array}$}} & \multirow{3}{*}{.998} & \multirow{3}{*}{3.12} & \multirow{3}{*}{.09} & \multirow{3}{*}{30.63} & \multirow{3}{*}{3.45} & \multirow{3}{*}{.99} & \multirow{3}{*}{4.15} \\
\hline & & & & & & & & \\
\hline $\begin{array}{c}\text { At the 1-per } \\
\text { level . . . . . . }\end{array}$ & $\begin{array}{l}\text { rcent } \\
\ldots \ldots\end{array}$ & & & & & & & \\
\hline
\end{tabular}

${ }^{1}$ Highly significant difference between the value thus identified and the one above it in the same column.

${ }^{2}$ Significant difference between the value thus identified and the one above it in the same column.

in the macropores largely explains the reduction in drainage and aeration associated with increased compaction.

The preliminary work herein reported is limited to the measurements of some compaction indices in the uppermost 7 inches of soil. There is evidence from research in other areas $(10,14)$ that annual tractor traffic in itself is capable of compacting soils to lower depths, even to depths of 24 inches, i.e., well below the reach of normal land preparation and cultivation operations when soil-moisture levels approximate the optimum moisture for tillage. Therefore, the tractor must be considered as a major contributing factor in inducing traffic soles or hardpans.

Free, et al., (4) found a definite relationship between the organic-matter level of a soil and its degree of compactability. Furthermore, in truck-crop areas in Long Island, N. Y., it has been found $(16,13)$ that there was a higher soil density in the spray-wheel middle than in the nonwheel middle, but 
the compaction was lessened with increased organic-matter levels. The continuous additions of organic residues in the form of trash and roots to sugarcane fields in Puerto Rico must be a factor in reducing compaction.

It might be well to recall at this time that it is of importance to recognize and carefully separate and define the different field situations that might be ordinarily considered as compaction problems. ${ }^{3}$ There are genetically developed compacted layers and traffic-induced (implement traffic, tillage operations, and livestock trampling) pans. Studies to improve structural conditions in heavy claypan soils have been conducted locally (7). The following tabulation shows the effect of deep tillage on the infiltration rate of a genetically compacted soil in east-central Puerto Rico:

Treatment

Eighth-hour inffiltration rate in./hr.

Undisturbed soil.................................. 0.5

Ordinary plowing and harrowing (4 times) $\ldots \ldots \ldots \ldots \ldots \ldots \ldots, \quad 5.6$

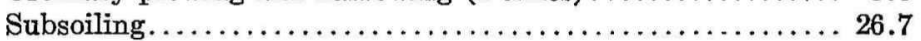

The infiltration capacity of this soil was increased tenfold by ordinary plowing and harrowing only. Digging down around the borders of the wetted area disclosed that most of the water entering the soil of the plowed and harrowed plots through the immediate surface moved laterally after reaching the claypan, rather than downward in the profile. Where the claypan was shattered by the subsoil standard the water moved downward through the disturbed layer (7).

Deep tillage might prove as effective in breaking induced pans as with genetically indurated layers. There is need for more extensive information concerning the probable impact of farm mechanization on soil properties. It is a problem challenging soil scientists and agricultural engineers as well. Much remains to be done in recognizing situations under field conditions, analyzing the factors responsible for such conditions, as well as the soil properties affected, and developing both preventive and corrective measures as well.

\section{SUMMARY}

A short discussion on the effect of heavy traffic on soil physical properties is presented. Soil cores were taken at 0-3- and 4-7-inch depths from rows of plots trampled by heavy tractor traffic and also from adjacent untrampled rows. The following physical properties were investigated: Bulk density, hydraulic conductivity, quick drainage, maximum saturation, total porosity, and water removal and retention at $\mathrm{pF}$ 1.78. Quick-drainage values indicated compaction due to tractor tires. The soil in the rows sub-

${ }^{3}$ Raney, W. A., et al., (11) present a good discussion on the necessity of recognizing different kinds of conditions restricting root penetration. 
jected to heavy traffic was denser, required more effort to sample, and its porosity was reduced somewhat, but water retention at low tensions was not affected.

The possibilities of deep tillage as a corrective measure are indicated, but stress is given to the development of sound preventive soil-management techniques.

\section{RESUMEN}

Se discute brevemente el efecto de tránsito de vehículos pesados sobre las propiedades físicas del suelo. Se tomaron cilindros de suelo a profundidades de $0-3^{\prime \prime}$ y $4-7^{\prime \prime}$ en hileras de parcelas sometidas al tránsito de vehículos pesados y en hileras adyacentes que no sufrieron los efectos del tránsito. Se investigaron las siguientes propiedades del suelo: Densidad aparente, conductividad hidráulica, desagüe rápido, saturación máxima, porosidad total y remoción y retención de humedad a pF 1.78. La medida de desagüe rápido indicó que el suelo en las hileras sometidas al tránsito pesado era mucho más compacto. También este suelo resultó ser mucho más denso y su porosidad se redujo, pero su habilidad de retener humedad a tensiones bajas no se afectó.

Se menciona la posibilidad de corregir esta situación por medio de labranzas profundas, pero se da énfasis a la necesidad de dar preferencia al desarrollo de técnicas de manipulación del suelo de naturaleza preventiva.

\section{LITERATURE CITED}

1. Brind, W. D., Some German and Austrian work on soil compaction and fertility, Soils and Fert. 15 (4) 227-30, 1952.

2. Bruce, R. R., An instrument for determining soil compactability, Soil Sci. Soc. Amer. Proc. 19 (3) 253-7, 1955.

3. Doneen, L. D., and Henderson, D. W., Compaction of irrigated soils by tractors, Agr. Eng. 34. (2) 94-5, 102, 1953.

4. Free, G. R., Lamb, J., Jr., and Carleton, E. A., Compactability of certain soils as related to organic matter and erosion, J. Amer. Soc. Agron. 39 (12) 1068-76, 1947.

5. Huberty, M. R., Compaction in cultivated soils, Trans. Amer. Geophys. Union 25 896-9, 1944.

6. Klute, A. and Jacob, W. C., Physical properties of Sassafras silt loam as affected by long time organic matter additions, Soil Sci. Soc. Amer. Proc. 14 (1) 24-8, 1949.

7. Martínez, M. B., and Lugo-López, M. A., Influence of subsoil shattering and fertilization on sugarcane production and soil infiltration capacity, Soil Sci. 75 (4) 307-15, 1953.

8. McKibben, E. G., and Green, R. L., Transport wheels for agricultural machines VII, Relative effects of steel wheels and pneumatic tires on agricultural soils, Agr. Eng. 21 (5) 183-5, 1940.

9. Nichols, M. L., Cooper, A. W., and Reaves, C. A., Design and use of machinery to loosen compact soil, Soil Sci. Soc. Amer. Proc. 19 (2) 128-30, 1955. 
244. JOURNAL OF AGRICULTURE OF UNIVIRSITY OF PUERTO RICO

10. Parker, E. R., and Jenny, H., Water infiltration and related soil properties as affected by cultivation and organic fertilization, Soil Sci. 60 (5) 353-76, 1945.

11. Raney, W. A., Edminster, T. W., and Allaway, W. H., Current status of research in soil compaction, Soil Sci. Soc. Amer. Proc. 19 (4) 423-8, 1955.

12. Reed, I. F., A method of studying soil packing by tractors, Agr. Eng. 21 (7) 281-2, 285,1940 .

13. Russell, M. B., Klute, A., and Jacob, W. C., Further studies on the effect of long time organic additions on the physical properties of Sassafras silt loam, Soil Sci. Soc. Amer. Proc. 16 (2) 156-9, 1952.

14. Weaver, H. A., Tractor use effects on volume weight of Davidson loam, Agr. Eng. 31 (4) 182-3, 1950. 